\title{
Além do Sol e Praia: diagnóstico do potencial turístico do Corredor Cultural de Natal (Rio Grande do Norte, Brasil)
}

\section{Besides the Sun and Beach: diagnosis of the tourism potential of the Cultural Corridor of Natal (Rio Grande do Norte, Brazil)}

\author{
Mayara Ferreira de Farias (FARIAS, M. F. de) ${ }^{*}$ \\ Marília Barbosa Gonçalves (GONÇALVES, M. B.) ${ }^{* *}$ \\ Carlos Alberto Freire Medeiros (MEDEIROS, C. A. F.) ${ }^{* * *}$
}

\begin{abstract}
RESUMO - Dado o potencial histórico-cultural presente na área definida como Corredor Cultural do município de Natal, capital do estado do Rio Grande do Norte (Brasil), e considerando as ações de revitalização que serão efetuadas neste, este artigo se justifica pela necessidade de promoção e comercialização da área como mais um produto turístico para a cidade, agregando ainda mais valor à oferta turística já oferecida e propiciando mais um ambiente de lazer para sua população. Considerando que para tornar o Corredor Cultural um produto turístico comercial, agregando valor ao já comercializado segmento de Sol e Praia do destino, visualizou-se a necessidade de desenvolver um plano de revitalização cultural, social e econômica que possibilitasse a criação da alma ao lugar. Esse estudo faz um diagnóstico da atual situação deste Corredor Cultural e sugere ações para sua melhor implementação, tendo como objetivo mostrar a relevância deste recurso turístico como agregador de valor para o destino turístico, permitindo que esse mude seu posicionamento perante o mercado e se torne mais competitivo. Para a realização deste diagnóstico foram utilizadas duas técnicas: a Matriz SWOT e a Tabela de Avaliação e Hierarquização dos Atrativos. Concluiu-se, ao final deste trabalho que a cidade de Natal necessita mudar e se posicionar melhor perante o mercado turístico. Para isso os representantes do governo e os empresários do setor turístico devem se concentrar nos gaps que faltam ser preenchidos e que estão apontados nos resultados deste artigo.
\end{abstract}

\footnotetext{
* Graduação em Turismo (Bacharelado) pela Universidade Federal do Rio Grande do Norte (UFRN); Mestranda em Turismo (UFRN/PPGTUR); Técnico em Informática pelo Instituto Federal de Educação, Ciência e Tecnologia do Rio Grande do Norte (IFRN); Guia de Turismo Regional pelo Serviço Nacional de Aprendizagem Comercial (SENAC); Bolsista REUNI - UFRN. Endereço para correspondência (Rua Getúlio Vargas, 42. CEP: 59220-000 - Coronel Ezequiel - RN (Brasil). Telefone para contato: (84) 88893215. E-mail: mayara_turismo_ufrn@hotmail.com

** Graduação em Turismo (Bacharelado) pela Universidade Federal do Rio Grande do Norte (UFRN); MBA em Marketing Estratégico pelo Centro Universitário do Rio Grande do Norte (UNI-RN); Mestranda em Turismo (UFRN/PPGTUR); Bolsista REUNI - UFRN. Endereço para correspondência: Rua César Barbosa, 70. CEP: 59240-000 - Tangará - RN (Brasil). Telefone para contato (84) 9902-4268. E-mail: mariliagoncalves_rn@hotmail.com

*** Graduação em Administração (Bacharelado) de Empresas pela Universidade Federal do Rio Grande
do Norte (UFRN), Mestrado em Administração (UFRN) e Doutorado em Administração pela
Universidade de São Paulo (USP). Professor Adjunto da Universidade Federal do Rio Grande do Norte
(UFRN). Professor do Programa de Pós-Graduação em Turismo - PPGTUR/UFRN. Endereço
Profissional: Universidade Federal do Rio Grande do Norte, Centro de Ciências Sociais Aplicadas,
Professor do Programa de Pós-Graduação em Turismo. Campus Universitário - Ed. Goiabão/CCSA,
Lagoa Nova. CEP: 59072-970 - Natal - RN (Brasil). Telefone: (84) 9982-2290. E-mail:
carlosalberto@ digi.com.br
} 
Palavras-chave: Corredor Cultural; Turismo Cultural; Marketing Turístico.

ABSTRACT - Given the historical and cultural potential in the area defined as the Cultural Corridor of Natal, capital of Rio Grande do Norte (Brazil), and considering the actions that will be made in this revitalization, this article is justified by the need to promote and commercialize the area as a tourism product over the city, adding even more value to the tourism offer and providing more recreational environment for its population. Considering that to turn the Cultural Corridor in a tourist attraction, adding value to the already marketed segment of sun and beach of the destination, it was visualized the need to develop a plan of cultural, social and economical revitalization that enabled the creation of the soul to the place. This study makes a diagnosis of the current situation of the Cultural Corridor and suggests actions for its better implementation, aiming to show the relevance of this tourist resource as a value aggregator to the tourist destination, allowing it to change its position before the market becomes more competitive. To carry out this diagnosis were used two techniques: SWOT Matrix and Evaluation and Hierarchy of the Attractions Table. It was concluded that Natal needs to change and be better placed in the tourist market. For that the government and tourism sector entrepreneurs should focus on gaps that remain to be completed and that results are highlighted in this article.

Key words: Cultural Corridor; Culture Tourism; Tourism Marketing. 


\section{INTRODUÇÃO}

O Brasil possui variados recursos, aparecendo em $23^{\circ}$ lugar como detentor de recursos culturais no estudo de competitividade do World Economic Forum (2011), e em $1^{\text {o }}$ lugar em recursos naturais. Chiozzini (2007) cita que segundo pesquisa encomendada pelo Ministério do Turismo "o turismo cultural aparece em terceiro lugar nas preferências daqueles que viajam pelo Brasil, só perdendo para o ecoturismo e para o turismo de aventura". As duas últimas modalidades fazem uso da imensidade de recursos naturais existentes no país. Segundo Brasil (2010c, p. 36), “estudos realizados em âmbito internacional apontam o crescimento das viagens em que a cultura é a motivação principal e demonstram as vantagens financeiras, sociais e ambientais resultantes do desenvolvimento do segmento".

Outra importante fonte de informação sobre o turista brasileiro, de acordo com Brasil (2010c, p. 38-39) é a pesquisa Hábitos de Consumo do Turismo Brasileiro - 2009 que revela as principais tendências da demanda do mercado turístico, onde se percebe que as viagens estão sendo cada vez mais relacionadas às experiências autênticas que um destino turístico pode oferecer, muitas delas relacionadas ao resgate do valor, da cultura e da história do destino. Grande parte dos entrevistados apontou o turismo a descanso e tranquilidade em $1^{\circ}$ lugar, com $43 \%$ da amostra, e a cultura em $3^{\circ}$ lugar, com $8,4 \%$, na relação de identificação com o turismo. Esses resultados vêm ao encontro do exposto por Ark e Richards (2006), de que a cultura atua como força motriz do sistema turismo cultural, e que o envelhecimento da população parece favorecer esse sistema.

Informações como essas servem para motivar a criação de leis que rejam o segmento do turismo cultural, bem como seus recursos, o patrimônio material e imaterial. No Brasil, as principais leis que conduzem o segmento no país, são apresentadas no Quadro 1. 


\begin{tabular}{|c|c|c|}
\hline LEGISLAÇÃO & $\begin{array}{c}\text { PRINCIPAIS } \\
\text { INSTRUMENTOS } \\
\text { LEGAIS }\end{array}$ & ESCOPO \\
\hline $\begin{array}{l}\text { Legislação } \\
\text { Turística }\end{array}$ & $\begin{array}{l}\text { Lei } 11.771 \text {, de } 17 \text { de } \\
\text { Setembro de } 2008^{1} \text {, } \\
\text { regulamentada pelo } \\
\text { Decreto } 7.381 \text {, de } 2 \\
\text { de Dezembro de } \\
2010^{2} \text {. }\end{array}$ & $\begin{array}{l}\text { Política Nacional de Turismo - define as atribuições do Governo } \\
\text { Federal no planejamento, desenvolvimento e estímulo ao setor } \\
\text { turístico, tendo como um de seus objetivos a conservação do } \\
\text { patrimônio natural, cultural e turístico brasileiro, passando a apoiar, } \\
\text { portanto, outros órgãos do Governo Federal no tocante à } \\
\text { preservação do patrimônio cultural brasileiro de interesse turístico, } \\
\text { conforme estabelecido no Art. 3, parágrafo único. } \\
\text { A Política Nacional do Turismo estabelecida pela Lei propõe, } \\
\text { ainda, que o MTur atue na preservação da identidade cultural das } \\
\text { comunidades e populações tradicionais eventualmente afetadas pela } \\
\text { atividade turística, refletindo no ordenamento e desenvolvimento } \\
\text { do segmento de Turismo Cultural na medida em que dá um } \\
\text { tratamento de importância a preservação da cultura brasileira, } \\
\text { explícita no inciso IX do Art. } 5 \text { da Lei do Turismo. No que } \\
\text { concerne ao Plano Nacional de Turismo, a preservação do } \\
\text { patrimônio deverá ser incorporada aos objetivos da Política de } \\
\text { Turismo, sempre quando realizar sua atualização (que ocorre de } 4 \\
\text { em } 4 \text { anos), definindo políticas e programas que se integrem a } \\
\text { outros setores das áreas pública e privada em favor do patrimônio } \\
\text { cultural do País. }\end{array}$ \\
\hline \multirow[t]{2}{*}{$\begin{array}{l}\text { Patrimônio } \\
\text { Cultural Material }\end{array}$} & $\begin{array}{l}\text { Decreto-Lei } 25 \text {, de } 30 \\
\text { de novembro de } \\
1937^{3}\end{array}$ & $\begin{array}{l}\text { Conceitua e organiza a proteção do patrimônio histórico e artístico } \\
\text { nacional e dispõe sobre o tombamento. }\end{array}$ \\
\hline & $\begin{array}{l}\text { Lei } \mathrm{n}^{0 .} 3.924 \text {, de } 26 \text { de } \\
\text { julho de } 1961^{4}\end{array}$ & $\begin{array}{l}\text { Dispõe sobre os monumentos arqueológicos e pré-históricos, sua } \\
\text { proteção, posse e salvaguarda. }\end{array}$ \\
\hline \multirow[t]{2}{*}{$\begin{array}{l}\text { Patrimônio } \\
\text { Cultural } \\
\text { Imaterial }\end{array}$} & $\begin{array}{l}\text { Decreto } n^{0 .} 3.551, \text { de } \\
4 \text { de agosto de } 2000^{5}\end{array}$ & $\begin{array}{l}\text { Institui o Registro de Bens Culturais de Natureza Imaterial que } \\
\text { constituem patrimônio cultural brasileiro, cria o Programa Nacional } \\
\text { do Patrimônio Imaterial e dá outras providências. }\end{array}$ \\
\hline & $\begin{array}{l}\text { Resolução } n^{\text {o. }} 001 \text { de } \\
2006^{6}\end{array}$ & $\begin{array}{l}\text { Regulamenta decreto } \mathrm{n}^{\circ} \cdot 3.551 / 00 \text { - determina os procedimentos a } \\
\text { serem observados na instauração e instrução do processo } \\
\text { administrativo de registro de bens culturais de natureza imaterial. }\end{array}$ \\
\hline
\end{tabular}

QUADRO 1 - LEIS QUE REGEM O TURISMO CULTURAL NO BRASIL.

FONTE: Adaptação do Manual de orientações básicas sobre turismo cultural (BRASIL, 2010c).

Diversos destinos turísticos internacionais, a exemplo da cidade do Rio de Janeiro já desenvolveram projetos de recuperação de seus patrimônios histórico-

${ }^{1}$ BRASIL. Lei 11.771, de setembro de 2008. Fonte: <http://www.planalto.gov.br/ccivil_03/_ato20072010/2008/lei/l11771.htm>.

2 BRASIL. Decreto 7.381, de 2 de Dezembro de 2010. Fonte: <http://www.planalto.gov.br/ccivil_03/_Ato2007-2010/2010/Decreto/D7381.htm>.

3 BRASIL. Decreto-Lei 25, de 30 de novembro de 1937. Fonte: <http://www.planalto.gov.br/ccivil_03/decreto-lei/del0025.htm>.

${ }^{4}$ BRASIL. Lei 3924, de 26 de julho de 196. Fonte: <http://www.planalto.gov.br/ccivil_03/leis/19501969/L3924.htm>.

5 BRASIL. Decreto 3551, de 4 de agosto de 2000. Fonte: <http://www.planalto.gov.br/ccivil_03/decreto/D3551.htm>.

IPHAN. Resolução 001, de 3 de agosto de 2006. Fonte: <http://portal.iphan.gov.br/portal/baixaFcdAnexo.do?id=1383>. 
culturais. "No Rio de Janeiro se iniciou uma discussão sobre seu corredor cultural ainda na década de 70, o que possibilitou a preservação de cerca de 1.600 prédios no centro da cidade" (IEB, 1992).

Além da recuperação da memória cultural de uma cidade, a restauração de um centro histórico tem o poder de atrair turistas. É o que assinala Chias (2007), quando afirma que eles "são polos que atraem como um imã uma infinidade de pessoas".

Sob essa perspectiva e trazendo esses dados para a realidade local, o Corredor Cultural de Natal tem sua área tombada pelo próprio município, o que é um fator relevante para sua efetiva restauração e implantação, como mostra a figura abaixo:

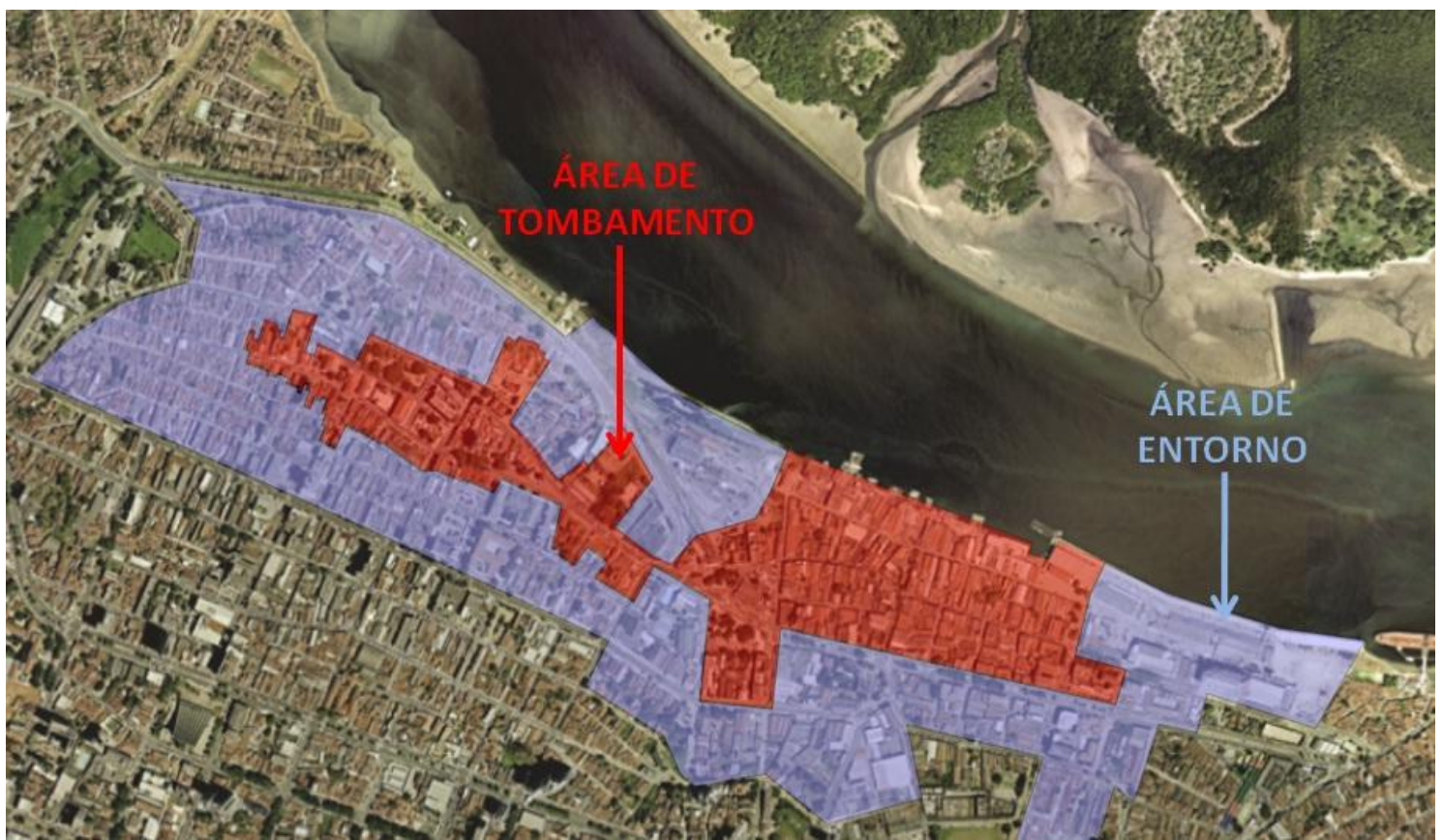

FIGURA 1 - ÁREA TOMBADA DO CORREDOR CULTURAL. FONTE: SETUR (2010).

Outros dados relevantes sob a óptica local foram evidenciados em pesquisa realizada pela SETURDE (2007), onde se observou que a grande maioria dos turistas que chegam a cidade de Natal foram motivados por atributos relacionados aos recursos naturais $(90,64 \%)$, principalmente as praias e ao litoral $(89,90 \%)$, enquanto apenas $1,72 \%$ dos turistas foram motivados pelos recursos culturais presentes na cidade, destes $1,40 \%$ motivados por manifestações populares e $0,32 \%$ motivados pelo patrimônio histórico-cultural da cidade. 
$\mathrm{Na}$ mesma pesquisa também se observa um número expressivo de turistas, brasileiros e estrangeiros, que não conhecem as manifestações populares e o patrimônio histórico-cultural da cidade, fato comprovado pelo desconhecimento apontado, que foi de $40,50 \%$ e $47,73 \%$ respectivamente, pois não souberam avaliar a qualidade dos mesmos, visto que não os conheciam.

Isso não quer dizer que seja falta de interesse ou de demanda dos turistas que visitam Natal/RN, pelo seu patrimônio histórico-cultural, mas talvez, pela falta de interesse dos empresários e da gestão pública que planeja e comercializa o destino Natal, focando somente o segmento Sol e Praia.

De acordo com Brasil (2010c, p. 36), a Organização Mundial do Turismo ${ }^{7}$ afirma que o segmento do turismo cultural corresponde a aproximadamente $10 \%$ do total das viagens internacionais e, ao considerar os dados das chegadas internacionais de turistas em $2008^{8}$, o segmento representou aproximadamente 92 milhões de viagens. E também que em 2005, uma pesquisa sobre o Turismo Cultural na Europa ${ }^{9}$ identificou uma forte tendência de crescimento da city break, a qual caracterizam como viagens de curta duração (final de semana ou feriados prolongados) para determinada localidade, tendo como motivação principal a oferta cultural desta.

O Estudo de Demanda Turística Internacional 2004 - 2008 (BRASIL, 2010b) reúne informações sobre o comportamento dos turistas internacionais que visitam o país, e de acordo com estes dados, em 2008, cerca de 16,9\% dos entrevistados tiveram a cultura brasileira como principal motivação das viagens a lazer realizadas no Brasil.

Para Brasil (2010c, p. 35) são considerados produtos do Turismo Cultural aqueles que têm a capacidade de atrair os visitantes, que lhes possibilitem formas de interação para vivenciar seus significados, garantam as condições adequadas para a visita, disponibilizem os serviços necessários para sua permanência e definem as circunstâncias para que a visita aconteça. Também consta que todos os atrativos culturais podem se transformar em produtos do Turismo Cultural, mesmo que nem todos atraiam o público igualmente, o que exige um cuidadoso trabalho de marketing

\footnotetext{
${ }^{7}$ OMT, UNDWTO, Tourism 2020 Vision. WTO: Madrid, 2001.

8 OMT, UNDWTO. Word Tourism Barometer. Madrid: OMT, September, 2009. Disponível em: <http://www.unwto.org>. Acesso em: 10/04/2013.

${ }^{9}$ OMT, UNDWTO. ETC. El Turismo Urbano y la Cultura: la experiencia europea. Madrid: OMT, 2005.
} 
para direcionar corretamente o produto aos seus respectivos mercados; mas com criatividade, sensibilidade, conhecimento e capacidade empreendedora acredita-se ser possível agregar valor e ampliar a atratividade.

Para tornar o Corredor Cultural um produto turístico comercial, agregando valor ao já comercializado segmento de Sol e Praia do destino Natal, considera-se ser necessário desenvolver um plano de revitalização cultural, social e econômica que recrie a alma do lugar.

Visto o potencial histórico-cultural presente na área definida como Corredor Cultural do município de Natal, e aproveitando-se das ações de revitalização que serão efetuadas neste, a proposição deste artigo se justifica pela constatação da necessidade de promoção e comercialização da área, produto turístico esquecido de Natal/RN, agregando, assim, ainda mais valor a oferta turística já oferecida pelo município, e condicionando mais um ambiente de lazer sociocultural ao natalense.

Vale salientar, embasando-se em Brasil (2010c, p. 53), que o Turismo Cultural não depende tanto das condições climáticas, como o Turismo de Sol e Praia ou outros segmentos cujas atividades são realizadas integralmente ao ar livre. Por isso, as viagens desse segmento podem acontecer ao longo de todo ano, sem grandes variações no fluxo de visitantes, sendo uma alternativa para a redução da sazonalidade nos destinos. Outra variável importante são os calendários das festas populares e eventos culturais, que funcionam muito bem na composição da oferta turística e como estratégia para ampliar o fluxo turístico nos períodos de baixa ocupação, com consequente aumento da taxa de ocupação dos equipamentos.

Porém, embora Natal seja conhecida pelo senso comum como a "Cidade do Sol", e assim propagada em outros slogans afins, evidenciando suas praias e belezas naturais, não se pode afirmar que isso faz dela uma referência no segmento Sol e Praia, uma vez que vários outros destinos regionais, nacionais e internacionais oferecem a mesma oferta e até algo mais.

Um destino que deseja atrair um maior número de turistas, ou melhorar sua "qualidade", necessita que os seus gestores cuidem de muitos fatores básicos, como infraestrutura, que atenda primeiramente a própria população e posteriormente ao turista. Depois disso, focar suas ações na imagem que se deseja passar, no público alvo que se deseja atingir, e no lugar o qual se quer ocupar na mente dos turistas. 
Considera-se que as atividades turísticas em Natal necessitam ser revisadas e atualizadas, buscando um melhor posicionamento perante o mercado turístico, e para que isso aconteça, governantes e empresários do setor devem se concentrar nas lacunas que faltam ser preenchidas para que esse turismo aconteça ativamente, diminuindo o enfoque no segmento de Sol e Praia, e investindo em segmentos, que embora tenham alto potencial de sucesso, parecem estar sendo desprezados.

Apenas ações publicitárias possivelmente não trarão o turista até o destino Natal, este é apenas um ponto a ser trabalhado dentro do marketing turístico do local. Os autores deste artigo ressaltam que, para que o destino em questão atinja um bom posicionamento no mercado e na mente do turista, as fragilidades da sua oferta precisam ser revistas e melhoradas.

Entende-se que os investimentos em publicidade interna e externa são transformados em ações já retrógradas, e nada sustentáveis, como o uso de panfletos e/ou outdoors, ambos causadores de poluição visual e ao meio ambiente.

A cidade conta com vários marcos/construções que enfatizam sua relevância histórica desde os períodos coloniais, como a Fortaleza dos Reis Magos, passando pelo envolvimento do município na Segunda Guerra Mundial, representado pelo prédio da Rampa (construído a beira do rio Potengi, servia de base para pouso dos hidroaviões durante a Segunda Guerra), até os dias atuais, com construções recentes de arquitetos consagrados, como Oscar Niemeyer. Porém, ainda se vende o mesmo "Sol e Praia" (com e sem emoção), uma segmentação secundária em níveis de interesse mundial, sem agregar ao menos um dos diferenciais que o destino possui.

Dentro desse contexto, o artigo traz em sua discussão outra faceta de Natal, pouco comercializada, mas de grande valor histórico-cultural não só para o local, podendo despertar o interesse de turistas até internacionalmente: seu Corredor Cultural. Este, quando visitado pelos turistas, como assim foi diagnosticado em city tour vivenciado pelos autores deste artigo, é percorrido rapidamente dentro de vans e ônibus turísticos, com rara possibilidade de saída dos veículos para visita a pé, devido à falta de infraestrutura da região, sem estacionamento exclusivo para os transportes turísticos, falta de segurança, más condições de travessia para o pedestre, entre outros fatores negligenciados. 
Esse estudo faz um diagnóstico da atual situação do Corredor Cultural de Natal, sugerindo melhorias a partir das falhas identificadas in loco. Tendo como objetivo mostrar a relevância deste recurso turístico, como agregador de valor para o destino Natal, permitindo supor que esse mude seu posicionamento (de ser apenas um destino de Sol e Praia) perante o mercado, e torne-se mais competitivo. Para a realização do diagnóstico foi utilizada a observação direta, a assistemática e a participante; a Matriz SWOT, e o modelo de Avaliação e Hierarquização dos Atrativos.

\subsection{POSICIONAMENTO DE NATAL COMO DESTINO TURÍSTICO}

Verifica-se que Natal é comercializada como um destino de Sol e Praia e é assim que se posiciona, porém, inovar no produto turístico que este destino oferece, implica em modificar e/ou ampliar sua oferta. Este artigo ressalta a potencialidade do Corredor Cultural como atrativo turístico, e como este poderia agregar valor aos produtos e serviços oferecidos pelo destino Natal, caso fosse comercializado. Ao vender seus recursos histórico-culturais, juntamente aos seus recursos naturais, Natal deixaria de ser somente um destino de sol e praia e teria algo mais a oferecer aos seus turistas. Além de possivelmente atrair um maior contingente de turistas, supostamente também aumentaria o tempo de permanência, por mais um ou dois dias, dos turistas que já vem à cidade para conhecer suas belezas naturais.

Ferraz, Trigueiro e Tinoco (2007) observam que Natal entrou na rota dos destinos mais procurados do país após os investimentos do PRODETUR/NE Programa de Desenvolvimento do Turismo/Nordeste - na cidade em meados dos anos 80. Silva (2003) destaca que em 2001 a capital potiguar passou a ocupar o quarto lugar entre as cidades brasileiras com o maior número de Hotéis, se tornando um dos destinos mais procurados do país no principal ramo do setor turístico que se desenvolveu na cidade: o Turismo de Sol e Praia.

Dias e Cassar (2005) afirmam que escolher uma estratégia de posicionamento é encontrar uma ou várias características no mercado escolhido e que representem para a organização um diferencial competitivo, isto é, algo que fará com que o cliente decida pelo produto dessa organização, e não pelo de seu concorrente. Logo, posicionamento oferece o diferencial necessário a uma organização, para ser reconhecida como diferente no mercado, mas identificada com seu consumidor. 
Cosma e Negrusa (2008) assinalam que o turismo cultural crescerá a taxas maiores que o setor do turismo em geral, para as autoras $60 \%$ dos turistas europeus estão interessados em descobrir o patrimônio cultural e 30\% dos destinos são escolhidos em função dos monumentos que podem ser visitados.

Em Brasil (2010c, p. 11) se aponta que nos últimos anos, novos produtos turísticos culturais vêm ampliando a percepção das possibilidades de interpretação e sentidos para os bens culturais do país, antes restrita ao patrimônio edificado e a algumas festas tradicionais brasileiras. Assim, as diversas combinações da cultura e do turismo configuram o segmento de Turismo Cultural, que é marcado pela motivação do turista de se deslocar especialmente com a finalidade de vivenciar os aspectos e situações que são peculiares da cultura brasileira.

\footnotetext{
A criação de produtos tematizados, utilizando técnicas de interpretação e de interação, que ressaltem a história do lugar e de seus personagens, para apresentar o patrimônio tangível e intangível do ambiente visitado, é uma forma de ampliar o conhecimento, possibilitar a fruição e emocionar o visitante. (BRASIL, 2010c, p. 16).
}

Para Kotler e Armstrong (1999, p. 174) a "posição de um produto é a forma como o produto é visto pelos consumidores quanto aos seus atributos mais importantes - é o lugar que ele ocupa na cabeça dos consumidores com relação aos produtos concorrentes." Nesta mesma linha, Dias e Cassar (2005, p. 159) destacam que "o mais importante ao definir um diferencial competitivo é responder à seguinte questão: o que fará o consumidor escolher o meu produto e não o de meu concorrente?”.

Além disso, segundo Dias e Cassar (2005) o uso de um slogan para identificar o atributo oferecido pela organização e que se destina a criar um diferencial competitivo é uma prática importante no marketing. Ou seja, além de facilitar a identidade entre produto e cliente, ele cria uma memória mais estruturada na mente desse último. É o que também afirmam Ries e Trout (2009), de que o posicionamento é o que se faz com a mente do cliente.

\subsection{A IMPORTÂNCIA DO PATRIMÔNIO HISTÓRICO PARA O TURISMO CULTURAL}

O Corredor Cultural de Natal apresenta riquezas materiais e imateriais, porém dar-se-á neste artigo foco apenas ao seu patrimônio histórico, uma vez que se observou 
que este precisa ser preservado para que as riquezas imateriais não desapareçam, por falta de espaço físico para se manifestarem.

Considera-se que o patrimônio histórico é uma vertente particular da ação desenvolvida pelo poder público para a instituição da memória social. O patrimônio se destaca dos demais lugares de memória uma vez que o reconhecimento oficial integra os bens a este conjunto particular, aberto às disputas econômicas e simbólicas que o tornam um campo de exercício de poder. (RODRIGUES, 1996).

O Turismo Cultural, de acordo com a cartilha do Ministério do Turismo, "compreende as atividades turísticas relacionadas à vivência do conjunto de elementos significativos do patrimônio histórico e cultural e dos eventos culturais, valorizando e promovendo os bens materiais e imateriais da cultura" (BRASIL, 2010c, p. 15). Tal cartilha ainda destaca que o Turismo Cultural implica em experiências positivas do visitante com o patrimônio histórico e cultural e com determinados eventos culturais, de modo a favorecer a percepção de seus sentidos e contribuir para sua preservação. $O$ conceito de vivenciar, ainda segundo a cartilha, estipula que:

Vivenciar significa sentir, captar a essência, e isso se concretiza em duas formas de relação do turista com a cultura ou algum aspecto cultural: a primeira refere-se às formas de interação para conhecer, interpretar, compreender e valorizar aquilo que é o objeto da visita; a segunda corresponde às atividades que propiciam experiências participativas, contemplativas e de entretenimento, que ocorrem em função do atrativo motivador da visita (BRASIL, 2010c, p. 15).

Para Funari e Pinsky (2005, p. 8) patrimônio cultural é tudo aquilo que constitui um bem apropriado pelo homem, com suas características únicas e particulares "abrange tudo que constitui parte do engenho humano e por isso, pode estar no cerne mesmo do turismo".

Para Rodrigues (1996, p. 22):

A finalidade do patrimônio, originalmente tida como a de representar o passado das nações, multiplicou-se. A partir de dois pontos de vista, muitas vezes tomados como antagônicos - o do poder público, que pretende a valorização dos bens como mercadorias culturais, e o de parte da sociedade, que o vê como um fator de qualidade de vida -, o patrimônio do Brasil oscila entre tornar-se um cenário teatralizado, como o Pelourinho, na Bahia, ou mal conservado, situação cujos exemplos são numerosos. 
O patrimônio histórico é essencial para atividade turística, prova disso são os museus, plenos de exposições, com equipe qualificada para atender aos mais diversos segmentos, os museus são espaços multifuncionais, que englobam de lazer a educação, transformada numa atividade rentável, e autossustentável, quando bem geridos.

Cidades como Londres, Paris e Nova York recebem grande número de turistas, nacionais e estrangeiros, em todas as épocas do ano. Ao lado de testemunhos arquitetônicos, parques, monumentos históricos, gastronomia e possibilidades de consumo diferenciado, seus visitantes contam com uma ampla gama de museus a ser conhecida. Aliás, uma visita a Londres está, quase sempre, associada ao British Museum; ao Louvre, no caso de Paris, e ao Metropolitan Museum, em Nova York. Essa estreita relação entre o turismo e os museus vem sendo construída ao longo do tempo, cujos elementos-chave podem ser entendidos como a existência de acervos consagrados, de um trabalho dinâmico de musealização e, finalmente, de estratégias de marketing direcionadas ao turismo. (GOMES, 2005, p. 27).

Em Natal foi observado, após visita in loco, que os museus estão um tanto quanto abandonados e esquecidos tanto pela população, como pelos próprios turistas, que em sua maioria provavelmente desconhecem a existência deles. É natural que os turistas que procuram Natal venham em busca de seus recursos naturais, pois é o mais comumente comercializado, porém com a promoção e comercialização do Corredor Cultural os museus e demais prédios históricos natalenses ganhariam destaque, pois a esse respeito como afirma Gomes (2005, p. 28):

À primeira vista, a relação dos museus de países desenvolvidos com o turismo pode nos parecer uma realidade intangível. Para alguns, o Brasil, famoso por suas praias e sua natureza exuberante, não possuiria instituições culturais capazes de atrair o interesse do turista, justificando, por exemplo, a inclusão da visita a um museu nas atividades de um pacote turístico.

Porém, promover o turismo cultural não é fazer desse o principal foco/segmento do país, mas sim utilizá-lo para agregar ainda mais valor à sua oferta turística. Como consta na cartilha de Orientações Básicas sobre Turismo Cultural, do Ministério do Turismo (BRASIL, 2010c, p. 32), a qual ressalta que:

O desenvolvimento e a promoção de atrativos relacionados ao Turismo Cultural, bem como de produtos e atividades culturais, integrados a outros segmentos, contribuem para a diversificação da oferta e diminuição do período de sazonalidade turística em determinados destinos cuja oferta turística tenha como vocação principal, outros segmentos de turismo, como por exemplo, o Turismo de Sol e Praia e o Turismo e Negócios e Eventos. 
Tal documento também ressalta que todos os atrativos culturais podem se transformar em produtos do Turismo Cultural, mas como nem todos têm o mesmo poder de atração e supostamente não existe algo que atraia todos os públicos, se pode afirmar que se o serviço do marketing direcionar corretamente o produto aos seus respectivos mercados; com criatividade, sensibilidade, conhecimento e capacidade empreendedora, se faz possível agregar valor e ampliar a atratividade.

Barretto (2000) sugere o uso do turismo cultural na transformação de um bem protegido num bem com utilidade social e viabilidade financeira, e propõe que cidades e prédios históricos, monumentos e manifestações culturais tradicionais sejam tratados de forma responsável como componentes do produto turístico, assim como o turismo seja um estímulo à manutenção da identidade das populações receptoras.

\section{CORREDOR CULTURAL: MAIS CULTURA, MAIS HISTÓRIA, MAIS NATAL}

A implantação do projeto do Corredor Cultural possibilitará ao turista uma opção a mais de entretenimento em Natal. De acordo com Brasil (2010a), a ideia partiu de uma iniciativa dos membros do Conselho de Turismo do Polo Costa das Dunas. Em seguida, o projeto foi incluído no PDITS - Plano de Desenvolvimento Integrado do Turismo Sustentável e, assim, foi formado um grupo de trabalho com a participação de membros da SETUR - Secretaria de Turismo do Estado, Prefeitura Municipal de Natal, SPU - Secretaria do Patrimônio da União, IPHAN - Instituto do Patrimônio Histórico e Artístico Nacional e Fundação José Augusto, que sob a coordenação do primeiro, elaboraram um Termo de Referência culminando com a celebração de um Convênio entre a SETUR e o MTUR para a realização do projeto executivo em julho de 2010.

Ainda segundo Brasil (2010a), previa-se que o Corredor Cultural, desde sua constituição, tivesse ações para preservação do patrimônio histórico cultural de todo seu circuito, através da revitalização dos prédios envolvidos, da sinalização das ruas, praças e monumentos e o apoio aos eventos e manifestações culturais. Porém, a partir do que foi diagnosticado após visita in loco dos autores deste artigo, percebe-se que tais ações, 
previstas a partir do Convênio SETUR e MTUR para o Corredor Cultural de Natal, não foram implantadas.

De acordo com Ferraz, Trigueiro e Tinoco (2007) embora a área seja reconhecida como Zona Especial de Preservação Histórica e alvo de projetos de revitalização desde a década de 1990, continua a apresentar problemas comuns a outros centros antigos brasileiros, tais como:

- o esvaziamento do uso residencial, bem como de grande parte dos edifícios de interesse histórico, alguns ocupados apenas nos pavimentos térreos, outros inteiramente vazios, outros, ainda semi ou totalmente arruinados;

- a negligência quanto aos espaços públicos;

- a alternância entre congestionamento, no horário comercial, e esvaziamento nas noites e fins de semana;

- a subutilização da infraestrutura urbana disponível;

- a sensação de perigo e medo que parece mais motivada pela decrepitude do ambiente construído do que pela efetiva ocorrência de delitos.

Os autores também lembram que em Natal, os processos de expansão urbana, deslocamento, dilatação e rarefação do centro ativo, acompanhados do surgimento de novos centros ocorrem a partir da segunda metade do século XX, intensificando-se nas últimas décadas. Como em tantas cidades no, e fora do, Brasil, a concorrência que essa rede de subcentros exerceu sobre o antigo centro da cidade, fez com que este se diluísse não só, em termos de função, mas também de percepção. Entretanto, diversamente do que ocorreu em outras cidades, nele não se definiu um novo conceito para o centro antigo, capaz de lhe agregar valores derivados da noção de memória e identidade.

Para completar, Ferraz, Trigueiro e Tinoco (2007) destacam que mesmo que os imóveis que preservam traços de arquiteturas de época possam conferir potencial turístico-cultural ao Corredor Cultural, não lhe garantem desenvolver o turismo como atividade econômica. Simão (2006, p. 65) reforça que o reconhecimento de um lugar apto ao turismo se dá, entre outros aspectos, pela identificação de um conjunto de recursos naturais ou culturais que constituem a base da atividade turística e garantem o fluxo dos turistas, somado aos equipamentos e serviços colocados diretamente à disposição dos turistas e à infraestrutura urbana que a cidade dispõe e disponibiliza indiretamente ao consumo dos turistas. 
O Diagnóstico para o Plano Estratégico Natal - Uma Metrópole Em Formação, elaborado pelo FADE ${ }^{10}$ (2006, p. 105) declara que a cidade de Natal apresenta a maior concentração e os principais edifícios de valor histórico da $\mathrm{RMN}^{11}$, aí estão $61 \%$ dessas edificações, sendo que $87 \%$ estão tombados pela Fundação Jose Augusto, $10 \%$ pelo IPHAN e 3\% sem tombamento. Ainda de acordo com o diagnóstico, esta concentração ocorre devido à própria história da cidade, núcleo inicial de ocupação do Estado ocorrida no final do século XVI.

No núcleo histórico de Natal - Cidade Alta e Ribeira - é onde se encontra o maior número de imóveis de valor histórico, artístico, cultural e arquitetônico e monumentos tombados. Outro importante fragmento é o Farol de Mãe Luiza, localizado próximo da praia de Areia Preta, no alto das dunas do bairro, e que não apresenta tombamento (FADE, 2006, p. 105)

O Corredor Cultural de Natal possui praças, museus e outros monumentos históricos com grande potencialidade turística. Ao revitalizar esse atrativo e toda infraestrutura básica da região, através de ações de benchmarking ${ }^{12}$, baseando-se nos principais e mais visitados Corredores Culturais do mundo, como os de Paris ou Barcelona, por exemplo, que serviram de referência, têm-se condições de comercializálo turisticamente, e por em prática atividades simples, como roteiros para pedestres, ciclistas, ou até mesmo através de transporte turístico específico.

Pelo que foi observado, os atrativos do Corredor Cultural possibilitam conhecimentos das mais variadas apreciações, seja sobre arquitetura, participações em acontecimentos, lugares que serviram de moradia a personagens ilustres e admirados, entre outros aspectos.

Comparando o Corredor Cultural de Natal com outros corredores do próprio país, e até mesmo do mundo, identificam-se diversos pontos em comum, como: vielas, antiquários, igrejas, museus, gastronomia local, e principalmente os bares e cafés que remetem aos tempos boêmios, nos quais os artistas se reuniam e trocavam ideias, escreviam poesias, pintavam quadros, dentre outras atividades.

\footnotetext{
${ }^{10}$ FADE - Fundação de Apoio ao Desenvolvimento da UFPE.

${ }^{11}$ Região Metropolitana de Natal.

12 Benchmarking é visto como um processo positivo e proativo por meio do qual uma empresa/organização examina como outra realiza uma função específica a fim de melhorar como realizar a mesma ou uma função semelhante.
} 
O Corredor Cultural delimita-se como mostra a Figura 2, apresentada a seguir:

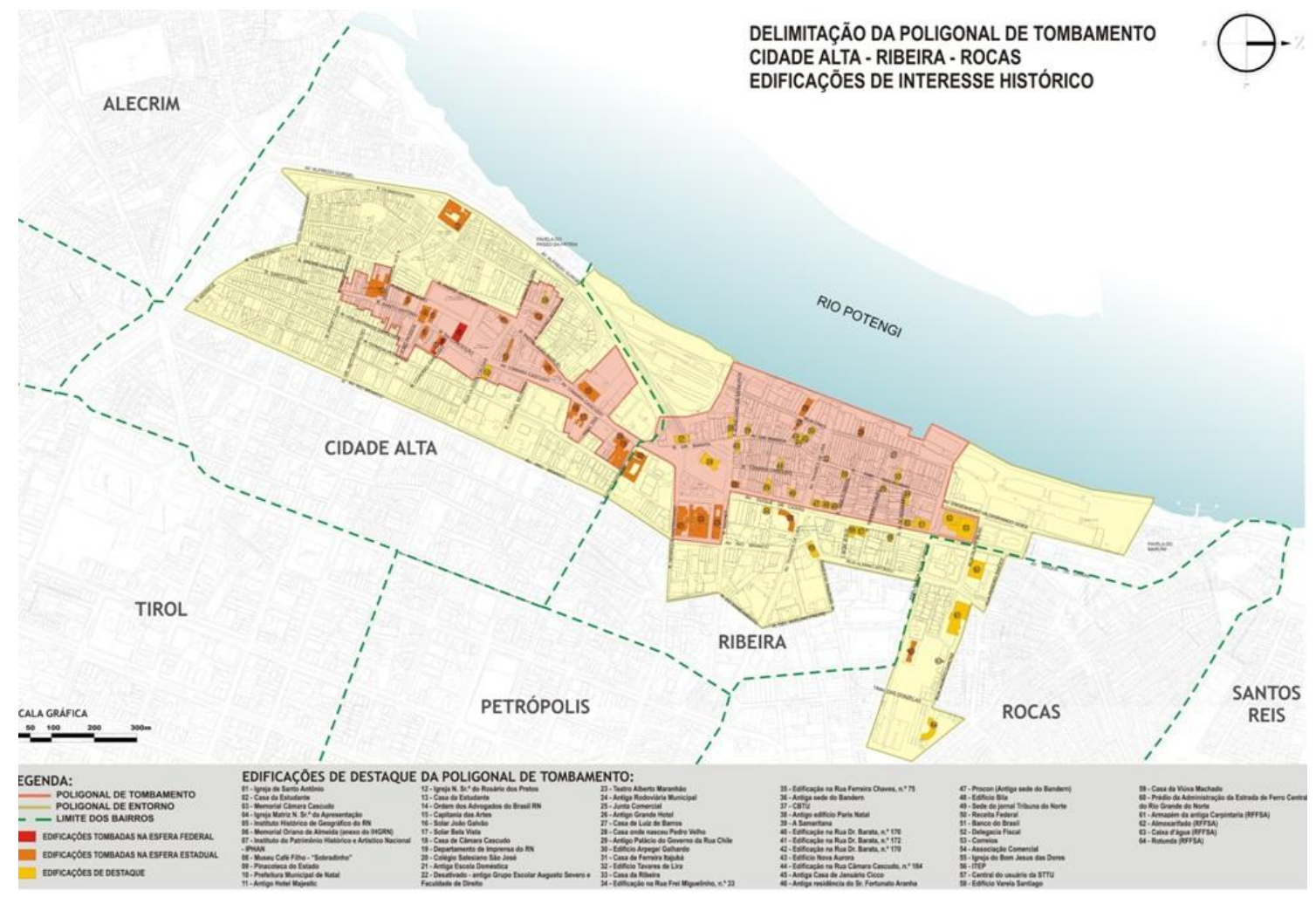

FIGURA 2 - CORREDOR CULTURAL DE NATAL.

FONTE: SETUR (2010).

Em vermelho estão as edificações tombadas em esfera federal; em laranja estão as edificações tombadas na esfera estadual; e em amarelo são edificações apenas de destaque no bairro. Dentre os três tipos de edificações destacadas no mapa, as que compõem o percurso do Corredor Cultural de Natal, segundo a SETURDE (2007), são: Pedra do Rosário; Igreja do Rosário; Casa da Viúva Machado; Praça André de Albuquerque Maranhão; Igreja Matriz Nossa Senhora da Apresentação; Memorial Câmara Cascudo; Convento Santo Antônio/ Igreja do Galo/Museu de Arte Sacra; Praça Padre João Maria; Instituto Histórico e Geográfico do RN/Coluna Capitolina; Casa do Padre João Maria/Iphan ; Museu Café Filho; Praça 7 de Setembro; Palácio Potengi ou Palácio da Cultura; Palácio Felipe Camarão; Igreja Presbiteriana; Casa da estudante; OAB - Ordem dos Advogados do Brasil; SESC - Serviço Social do Comércio (relógio do SESC); Praça das mães; Fundação Capitania das Artes; Solar João Galvão; Solar Bela Vista; Travessa Pax; Casa de Luis da Câmara Cascudo; A República - Imprensa Oficial; Colégio Salesiano São José; Caixa Econômica Federal; Praça Augusto Severo; 
Antigo Prédio da Escola Doméstica de Natal; Antigo Prédio do Grupo Escolar Augusto Severo/Antiga Faculdade de Direito; Antiga Estação Ferroviária; Teatro Alberto Maranhão; Antigo Prédio da Junta Comercial.

Assim, na perspectiva de mostrar os principais interessados no desenvolvimento de um plano de atuação mais eficaz, pontuou-se, através do plano de marketing, o público-alvo do Corredor Cultural de Natal, como apresentado no Quadro 2.

\begin{tabular}{|c|c|}
\hline \multicolumn{2}{|l|}{ PESSOA FÍSICA } \\
\hline Geográficos* (países, regiões, cidades, bairros). & $\begin{array}{l}\text { Principais países emissores: Portugal, Espanha, } \\
\text { Itália, Argentina. Principais estados emissores: } \\
\text { São Paulo, Pernambuco, Rio de Janeiro, Paraíba, } \\
\text { Rio Grande do Norte. Próprios moradores da } \\
\text { localidade, bem como das demais cidades do } \\
\text { estado. }\end{array}$ \\
\hline Demográficos (sexo, idade, renda, educação). & $\begin{array}{l}\text { Pessoas de todos os sexos, idade, e nível de } \\
\text { escolaridade. }\end{array}$ \\
\hline Psicográficos: estilos de vida, atitudes. & Pessoas interessadas em história e cultura. \\
\hline $\begin{array}{l}\text { Comportamentais (ocasiões de compra, hábitos de } \\
\text { consumo, benefícios procurados, taxas de uso). }\end{array}$ & Procuram por conhecimento e lazer \\
\hline \multicolumn{2}{|l|}{ PESSOAS JURÍDICAS } \\
\hline Geográficos (países, regiões, cidades, bairros) & $\begin{array}{l}\text { Empresas brasileiras, principalmente do } \\
\text { Nordeste e Sudeste. }\end{array}$ \\
\hline $\begin{array}{l}\text { Características Gerais (ramo de atividade, serviços } \\
\text { e produtos oferecidos, número de empregados, } \\
\text { filiais, tempo de atuação no mercado, imagem no } \\
\text { mercado). }\end{array}$ & $\begin{array}{l}\text { Agências de Turismo, hotéis e pousadas, } \\
\text { locadoras, restaurantes. }\end{array}$ \\
\hline $\begin{array}{l}\text { Comportamentais (ocasiões de compra, hábitos de } \\
\text { consumo, benefícios procurados, taxas de uso) }\end{array}$ & $\begin{array}{l}\text { Análise de mercado (empresas que pretendem se } \\
\text { instalar na região; Famtur etc.) }\end{array}$ \\
\hline
\end{tabular}
QUADRO 2 - PÚBLICO ALVO DO CORREDOR CULTURAL, 2011 (MODELO SEBRAE). Fonte: SETUR (2008).

Analisando os interesses do público-alvo, chegou-se às seguintes considerações:

- Comunidade local interessada nos eventos socioculturais, como também em conhecer a própria história da sua cidade (visto identificar-se que muitos a desconhecem);

- Estudantes do nível básico ao acadêmico em busca de visitas técnicas, ou em busca de pesquisas científicas;

- Empresas do ramo turístico que estejam estudando o mercado, visando abrir uma empresa ou instalar uma filial, bem como agências conhecendo o destino em Fam $\operatorname{tur}^{13}$, dentre outras atividades;

\footnotetext{
${ }^{13}$ Viagem de familiarização do destino, geralmente feita por agentes de viagens que vão vendê-lo. A viagem é patrocinada pelas empresas e organizações turísticas interessadas na comercialização do destino.
} 
- Turistas nacionais que buscam conhecer um pouco mais sobre a história do seu país, e da localidade a qual visitam, bem como os que viajam em busca de eventos socioculturais;

- Turistas internacionais interessados na memória do período colonial, e/ou Segunda Guerra Mundial.

Ferraz, Trigueiro e Tinoco (2007) relembram que o apelo turístico de Natal fundamenta-se, até agora, no valor paisagístico de sol, mar, dunas e nos prazeres sensoriais comumente associados a ambientes tropicais. E que a ideia de turismo cultural continua restrita a uma elite que detém, quase exclusivamente, o privilégio do conhecimento e da fruição desses bens, e que costuma fazê-lo com maior frequência fora de Natal e do Brasil. Para os autores, embora alvissareiro, o recente interesse oficial por essa alternativa a um turismo que apresenta aspectos socioculturais muito predatórios parece, ainda, uma possibilidade distante, quiçá alguma parcela do patrimônio construído resista até lá.

\subsection{DIAGNÓSTICO}

De acordo com o portal do Ministério do Turismo Brasileiro (BRASIL, 2010d), o Brasil possui 18 (dezoito) bens considerados patrimônio da humanidade pela UNESCO - Organização das Nações Unidas para a Educação, a Ciência e a Cultura -, dos quais, 10 correspondem a monumentos histórico-culturais, e 8 a naturais. $\mathrm{O}$ portal também traz que em 1972, a UNESCO criou a Convenção do Patrimônio Mundial, para incentivar a preservação de bens culturais e naturais considerados significativos para a humanidade, pelo fato de que o patrimônio cultural está cada vez mais ameaçado de destruição, tanto pela deterioração normal decorrente de fatores naturais, como por mudanças nas condições econômicas e sociais que agravam a situação, dentre as quais estaria o turismo de massa.

Embora cada região do Brasil tenha seus representantes na listagem dos locais tombados, segundo a nota do Ministério do Turismo, o Nordeste é a região que possui o maior número, sendo 7 locais tombados, onde 4 são patrimônios histórico-culturais, sendo eles: Centro histórico de São Luís do Maranhão, Olinda, Salvador e Praça de São 
Francisco, localizada na cidade de São Cristóvão, em Sergipe. Há o destaque nesse tópico para os patrimônios de cunho histórico-culturais, devido à temática deste artigo.

Assim, uma figura comparativa (Figura 3) foi esquematizada, mostrando quais são as possíveis localidades e atrativos concorrentes, nos contextos internacional, nacional, regional e local; ao mesmo tempo em que serve de Benchmarking para o planejamento de ações que façam de Natal um lugar conhecido não só pelas suas belezas naturais:

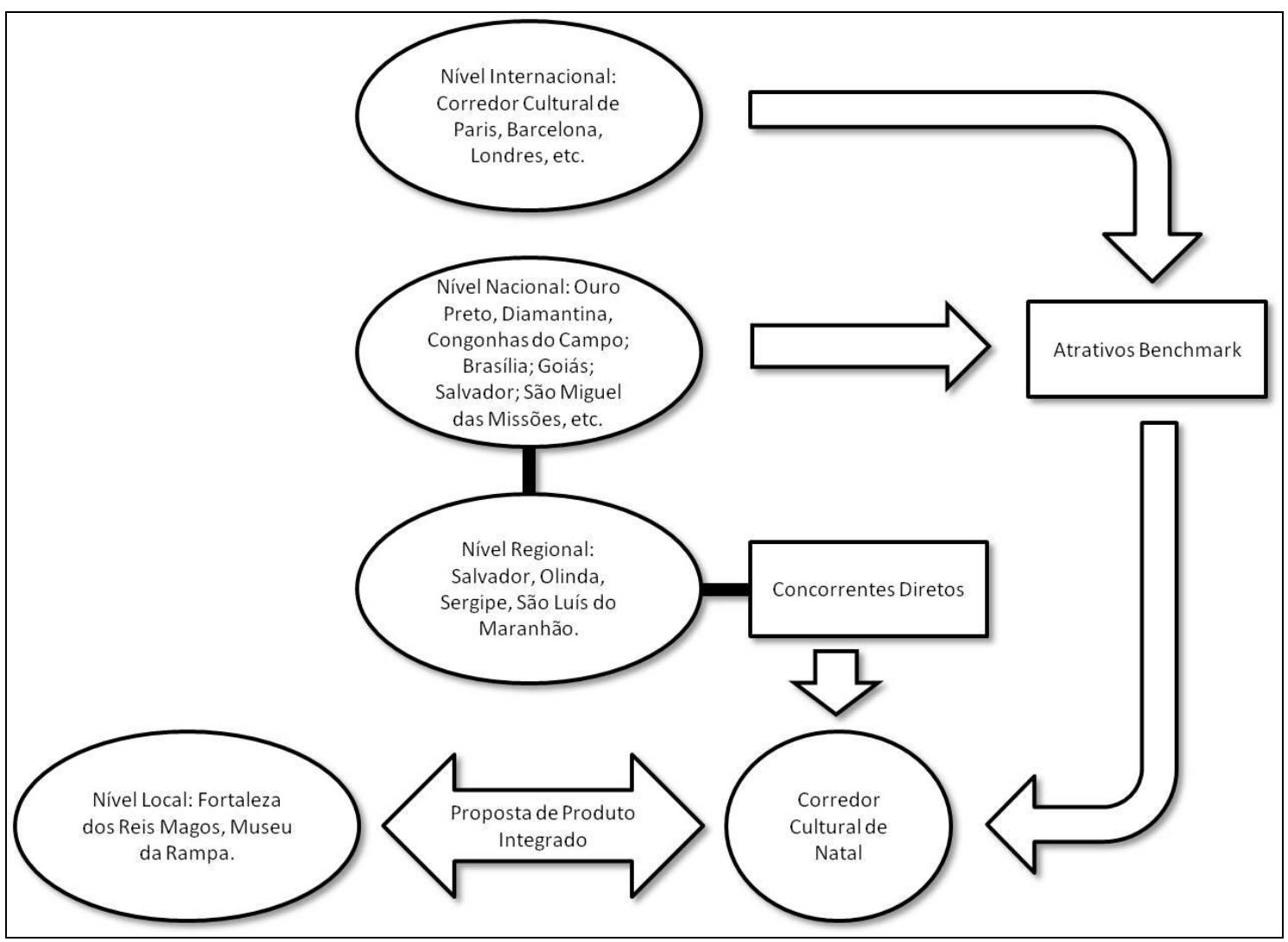

FIGURA 3 - BENCHMARKING E CONCORRÊNCIA.

Fonte: Elaborado pelos autores.

Dentro das categorias "nacional" e "regional", estão os 10 destinos brasileiros que possuem bens tombados como patrimônio histórico da humanidade. Ao observar o esquema, percebe-se que a cidade de Salvador aparece duas vezes, tanto na categoria nacional, quanto na regional. Salvador foi colocada na categoria regional devido suas características geográficas, ou seja, por fazer parte da região Nordeste, porém, por destacar-se como grande receptora de turistas, frente às demais capitais nordestinas, ela concorre diretamente com os demais destinos nacionais, também tombados. Suas 
concorrentes regionais não foram levadas em conta, pois embora Olinda seja também muito conhecida, ela e sua capital, Recife, bem como os demais destinos nordestinos tombados, atraem bem menos turistas, como mostra o quadro a seguir:

QUADRO 3 - FLUXO DE TURISMO INTERNACIONAL

\begin{tabular}{|l|c|c|c|}
\hline \multicolumn{1}{|c|}{ Estado } & $\mathbf{2 0 0 9 / 1 0}$ & $\mathbf{2 0 1 0} / \mathbf{1 1}$ & $\mathbf{2 0 1 1 / 1 2}$ \\
\hline Bahia & 141.000 & 160.000 & 166.000 \\
\hline Ceará & 88.000 & 79.000 & 84.000 \\
\hline Pernambuco & 71.000 & 61.000 & 63.000 \\
\hline
\end{tabular}

Fonte: Anuário do Ministério do Turismo (BRASIL, 2012).

O quadro aponta o fluxo de turismo internacional nos últimos anos nos estados nordestinos e, como se percebe, a Bahia está na liderança em todos os anos. O portal do governo da Bahia (BAHIA, 2013) noticiou sobre este Anuário 2012, que foi divulgado pelo Ministério do Turismo, a respeito dos números do setor, com base no ano de 2011 e confirmou a Bahia como o principal destino turístico do Nordeste. Entre 2011 e 2012, o estado teve 166 mil desembarques diretos de turistas estrangeiros, superando a soma dos vizinhos Ceará (84 mil) e Pernambuco (61 mil). No total, a Bahia teria recebido 558 mil estrangeiros no mesmo ano, contando os visitantes internacionais que chegaram por outros portões de entrada do Brasil como São Paulo, Rio de Janeiro e Distrito Federal, além dos outros estados do Nordeste. O Portal da Bahia ainda ressalta que o número corresponde a $10 \%$ do total de turistas internacionais recebidos pelo Brasil no período, segundo dados da Fundação Instituto de Pesquisas Econômicas (FIPE).

\subsection{ANÁLISE SWOT DO CORREDOR CULTURAL DE NATAL}

A Análise SWOT, segundo Silva et al. (2011), é creditada a Albert Humphrey (ou FOFA em português) permitindo identificar as Forças e Fraquezas (Strenghts e Weakness) de um atrativo, ou seja, seus fatores de criação (ou destruição) de valor; e as Oportunidades e Ameaças (Opportunities e Threats, respectivamente), são os fatores externos da criação (ou destruição) de valor, os quais não se pode controlar, mas que emergem da dinâmica competitiva do mercado, fatores demográficos, econômicos, dentre outros. Ao analisar o Corredor Cultural de Natal a partir da análise SWOT, pôdese destacar os seguintes pontos: 
Forças: a) relevância histórico-cultural no que se refere à quantidade de monumentos que possuem valor histórico da cidade e até mesmo que influenciaram, direta ou indiretamente, o desenvolvimento da mesma e do próprio estado; b) área tombada, um reconhecimento que possibilita fidelização e atração de um maior número de turistas a conhecerem o local; c) variedade de atrativos histórico-culturais, que possibilita ao turista/visitante escolher com mais liberdade o que vai conhecer, podendo montar seu próprio roteiro de visitação, separando por monumentos e poder voltar mais de uma vez a realizar o percurso; d) possui atualmente eventos culturais que incentivam a participação do artista local, fazendo com que o bairro fique mais movimentado e possibilite maior interação entre moradores/comunidade local e turistas/visitantes; e) região comercial e centro político, gerando, de certa forma, uma atratividade diante os lugares que turistas gostam de visitar; f) possui proximidade a outros atrativos relevantes (Fortaleza dos Reis Magos, praias, Rio Potengi, Rampa) diversificando a oferta turística da cidade.

Fraquezas: a) falta de iluminação noturna, o que inviabiliza visitações neste horário, por motivos de segurança; b) faltam locais destinados a estacionamento de vans, ônibus e carros, inviabilizando que estes veículos parem/estacionem e permitam o conhecimento interno dos estabelecimentos do Corredor Cultural pelos turistas; c) falta de boa estrutura de transporte público; d) falta de segurança e proximidade a bairros "perigosos", o que cria um estereótipo negativo da região; e) roteiro mal utilizado pelas agências de viagens, que se restringem apenas à realização de city tours em vans e em ônibus que não permitem adentrar aos estabelecimentos; f) desvalorização do natalense pela própria história, o que compromete a divulgação "boca a boca"; g) falta de infraestrutura nas ruas para mobilização do pedestre, o que compromete a realização do percurso feito sem transportes; h) descaso do setor público, fator que inviabiliza a restauração dos prédios, praças, museus e igrejas que constituem o corredor cultural (a questão da gestão perpassa e sobrepõe-se não pelo fator econômico, mas pela falta de visão e respeito à cultura da comunidade natalense); i) despovoamento da região, fator que dificulta a interação entre turistas e comunidade local e permite que o bairro seja rotulado como perigoso e marginalizado.

Oportunidades: a) turismo histórico-cultural ainda é o segmento pelo qual as pessoas mais viajam no mundo; b) diferenciação e ampliação de possibilidades de 
visitação turística, possibilitando o aumento do fluxo turístico para Natal e para o estado; c) aproveitar-se dos recursos destinados às melhorias das cidades-sedes, em prol da Copa do Mundo de Futebol da FIFA 2014; d) Aumento do número de turistas devido a Copa 2014.

Ameaças: a) falta de incentivo político, fazendo com que o Corredor Cultural, após implantado, não se sustente como uma alternativa de visitação; b) o Corredor ser substituído por outro atrativo cultural da cidade, pelas agências de viagens, devido às diversas inviabilidades supracitadas; c) cidades, ou estados vizinhos despontarem como referência no turismo histórico-cultural, comprometendo no momento da escolha por parte do turista, aliado ao fato de as agências relutarem em continuar vendendo apenas o segmento Sol e Praia.

\subsection{AVALIAÇÃO E HIERARQUIZAÇÃO DO ATRATIVO CORREDOR CULTURAL}

Uma avaliação e hierarquização, de forma geral, do Corredor Cultural de Natal, baseadas na metodologia utilizada pela Organização Mundial do Turismo (OMT) e pelo Centro Interamericano de Capacitação Turística (CICATUR) para a hierarquização de atrativos turísticos, proposta pelo Ministério do Turismo (BRASIL, 2005), foi feita pelos autores deste artigo. "O intuito da aplicação dessa metodologia é auxiliar na avaliação do grau de importância dos atrativos identificados para inclusão no roteiro turístico" (BRASIL, 2004, p. 12).

Com este instrumento são estabelecidas prioridades para determinar a escolha e as decisões dos governantes, administradores, gestores e empreendedores que pretendem investir em determinada localidade com potencial turístico.

A metodologia explica como o quadro foi elaborado, sendo em primeiro lugar avaliado o potencial de atratividade do elemento inventariado conforme as características e peculiaridades e o interesse que pode despertar nos turistas, baseado no quadro abaixo: 


\begin{tabular}{|l|l|}
\hline Hierarquia & Características \\
\hline $\mathbf{3}$ (alto) & $\begin{array}{l}\text { É todo o atrativo turístico excepcional e de grande interesse, com significação para o } \\
\text { mercado turístico internacional, capaz de, por si só, motivar importantes correntes de } \\
\text { visitantes, atuais e potenciais. }\end{array}$ \\
\hline $\mathbf{2}$ (médio) & $\begin{array}{l}\text { Atrativos com aspectos excepcionais em um país, capazes de motivar uma corrente } \\
\text { atual ou potencial de visitantes deste país ou estrangeiro, em conjunto com outros } \\
\text { atrativos próximos a este. }\end{array}$ \\
\hline $\mathbf{1}$ (baixo) & $\begin{array}{l}\text { Atrativos com nenhum aspecto expressivo, capazes de interessar visitantes oriundos de } \\
\text { lugares do próprio país, que tenham chegado à área por outras motivações turísticas, ou } \\
\text { capazes de motivar fluxos turísticos regionais e locais (atuais e potenciais). }\end{array}$ \\
\hline 0 (nenhum) & $\begin{array}{l}\text { Atrativos sem méritos suficientes, mas que formam parte do patrimônio turístico como } \\
\text { elementos que podem complementar outros de maior hierarquia. Podem motivar } \\
\text { correntes turísticas locais, em particular demanda de recreação popular. }\end{array}$ \\
\hline
\end{tabular}

QUADRO 4 - DESENVOLVIMENTO DO POTENCIAL DE UM ATRATIVO TURÍSTICO.

Fonte: Programa de Regionalização do Turismo - Roteirização Turística (BRASIL, 2005).

Expostos os critérios de pontuação, a próxima etapa, de acordo com Brasil (2005) é o processo de hierarquização dos atrativos turísticos, que atendem os seguintes critérios:

- Grau de uso atual: visando analisar o volume de fluxo turístico efetivo e a importância que adquire frente ao município;

- Representatividade: diz respeito à singularidade ou raridade do atrativo, quanto mais semelhante a outros atrativos, menos interessante ou prioritário;

- Apoio local e comunitário: com o intuito de analisar o grau de interesse da comunidade local para o desenvolvimento e disponibilidade ao público;

- Estado de conservação da paisagem circundante: verificar, através do estudo de campo o estado de conservação da paisagem que circunda o atrativo;

- Infraestrutura: através do estudo in loco, verificar se existe infraestrutura disponível no atrativo e o seu estado; e,

- Acesso: verificar as vias de acesso existentes e as condições de uso destas.

Assim, estruturou-se a Tabela 1, no qual seu maior somatório resultaria em 135 pontos: 


\begin{tabular}{|c|c|c|c|c|c|c|c|c|}
\hline Atrativo & 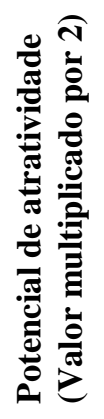 & 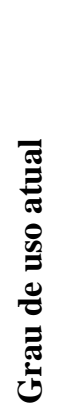 & 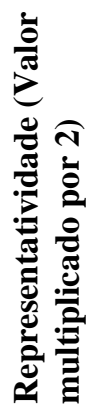 & 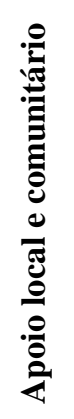 & 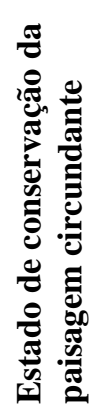 & 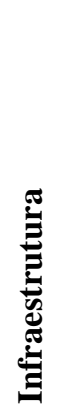 & $\frac{8}{0}$ & 恶 \\
\hline Atrativos Naturais & 2 & 1 & 1 & 2 & 1 & 1 & 2 & 13 \\
\hline Atrativos Culturais & 2 & 1 & 2 & 1 & 2 & 2 & 1 & 15 \\
\hline $\begin{array}{l}\text { Atividades } \\
\text { Econômicas }\end{array}$ & 2 & 1 & 1 & 1 & 1 & 1 & 1 & 11 \\
\hline $\begin{array}{l}\text { Realizações } \\
\text { Técnicas, Científicas } \\
\text { e Artísticas }\end{array}$ & 1 & 1 & 1 & 1 & 1 & 1 & 1 & 09 \\
\hline $\begin{array}{l}\text { Eventos } \\
\text { Programados }\end{array}$ & 1 & 1 & 1 & 1 & 2 & 1 & 1 & 10 \\
\hline
\end{tabular}

TABELA 1 - AVALIAÇÃO E HIERARQUIZAÇÃO DE ATRATIVOS DO CORREDOR CULTURAL DE NATAL/RN.

Fonte $^{14}$ : Programa de Regionalização do Turismo - Roteirização Turística (BRASIL, 2005).

Devido esta avaliação ter sido feita antes das reformas projetadas para o local, a tabela acima resulta no valor de 58 pontos, não chegando à metade do valor máximo, porém, após a revitalização do Corredor Cultural supõe-se que este valor aumente.

\subsection{ESTRATÉGIAS DE MARKETING}

Após a realização do diagnóstico do Corredor Cultural de Natal, foi possível elaborar estratégias de marketing, visando o fortalecimento, consolidação, promoção e venda do produto, visando expressar sua relevância com a intenção de colocá-lo ao nível dos principais produtos de Sol e Praia, já comercializados por Natal.

Assim, este tópico elenca as principais propostas de ação e implementação de estratégias de marketing para o Corredor Cultural de Natal:

\footnotetext{
${ }^{14}$ Tabela preenchida de acordo com a avaliação feita do atrativo Corredor Cultural de Natal pelos autores, a partir do modelo fornecido pelo Programa de Regionalização do Turismo - Roteirização Turística (BRASIL, 2005).
} 
a) Produto:

A estratégia do produto deverá considerar a consolidação do Corredor Cultural como produto turístico e sua inserção no mercado de turismo de Natal, sob uma nova perspectiva, na qual os atrativos culturais agregarão ainda mais valor à oferta turística já comercializada. Isso pode ocorrer de forma que incentive uma maior participação tanto da comunidade local, como de turistas (nacionais e internacionais), em sua realização.

Aos atrativos do Corredor Cultural de Natal, propõe-se adicionar os seguintes diferenciais, para que assim despertem ainda mais a atenção da população e do turista: eventos culturais; feiras artesanais de artistas locais; capacitação dos profissionais que trabalham no Corredor Cultural; uso de tradutores digitais para explicação nos atrativos, sinalização turística, entre outros. Além disso, também deverão ser feitas campanhas e incentivos que estimulem a revitalização do local, num contexto não somente comercial, como também residencial, visto a quantidade de casas, prédios e terrenos, muitas vezes abandonados, que há no espaço delimitado do Corredor, bem como em seu entorno.

b) Praça:

A estratégia de praça deverá proporcionar a realização de parcerias com agências de viagens e turismo; locadoras de automóvel; instituições públicas e privadas de ensino; estabelecimentos comerciais localizados no trajeto; guias de turismo local e regional, bem como com os estabelecimentos escolhidos para a entrada dos partícipes do Corredor Cultural.

c) Promoção:

Além do marketing "boca a boca", a promoção do Corredor Cultural deverá ocorrer através das mídias televisiva e rádio, impressa, e digital.

d) Mídia Televisiva e Rádio:

$\mathrm{Na}$ TV local deverão ser veiculados pequenos filmes/vídeos que apresentem aspectos sobre a história da cidade e mostrem a relevância do patrimônio presente no Corredor Cultural, incentivando principalmente os autóctones a conhecerem sua história. Bem como a divulgação dos eventos realizados no Corredor Cultural.

Nas rádios locais a propaganda poderia ser através de jingle ${ }^{15}$, para que este possa além de se fixar na mente do ouvinte, atraí-lo até o Corredor Cultural. A

\footnotetext{
${ }^{15}$ Um jingle é uma mensagem publicitária musicada e elaborada com um refrão simples e de curta duração, a fim de ser lembrado com facilidade. Fonte: Wikipédia, 2013. Disponível em: <http://pt.wikipedia.org/wiki/Jingle>.
} 
divulgação dos eventos que são realizados no Corredor Cultural também poderia ser feita pelas emissoras de rádio.

e) Mídia Impressa:

Há a necessidade de serem produzidos folhetos contendo todo o percurso do Roteiro Pedestre do Corredor Cultural, bem como a indicação de como se chegar até ele, seja por transporte público ou privado, locais para refeição, telefones úteis. Tais folhetos necessitam ser distribuídos em hotéis, restaurantes, aeroporto, centros de artesanato, outros atrativos turísticos, e postos de informação turística.

Além dos folhetos o Corredor Cultural, poderia ser promovido em revistas de cunho local, como a Solto na Cidade, e também nacionalmente, como, por exemplo, a Viagem e Turismo (editora Abril). Além das revistas próprias das companhias aéreas.

f) Mídia Digital:

A divulgação via mídia digital necessita ser feita através dos totens informatizados, geralmente localizados em zonas turísticas da cidade.

Via web site, um portal no qual pode constar, resumidamente, a história dos atrativos que compõem o Corredor Cultural, as sugestões de roteiro, links para sites dos outros atrativos da localidade, bem como as demais informações úteis (sobre pousadas, bares, restaurantes, agências de turismo, guias de turismo, locadoras de automóveis, devendo estes pagar uma taxa por publicidade, a qual manterá o site ativo e atualizado).

O portal necessita ser feito em $360^{\circ}$, possibilitando ao usuário conhecer todo o Corredor Cultural, através de imagens de alta definição, estimulando, assim, sua visita. Além disso, devem ser distribuídos banners em sites e blogs (locais, regionais e nacionais) de visitação massiva.

Via mídias sociais, com conta no Instagram (disponibilizando fotos do Corredor Cultural, bem como fotos compartilhadas pelos visitantes que estiveram pelo local); perfil no Twitter (divulgando as notícias e atualizações do Corredor Cultural), Fan Page no Facebook (onde os visitantes poderão compartilhar sua opinião e emoções sobre o Corredor Cultural, além de fotografias), e um canal no Youtube (com os vídeos comerciais do Corredor Cultural, bem como vídeos amadores gravados por visitantes que estiveram circulando pelo atrativo). 


\section{g) Pessoas:}

As pessoas envolvidas em todo o Projeto do Corredor Cultural devem passar por um treinamento para padronização de atendimento. Onde poderão ser aconselhadas a usar uniforme adequado, que identifique os funcionários de cada espaço visitado, capacitados através de cursos, em especial em um curso de língua estrangeira - Inglês, por ser uma língua universal, além de serem beneficiados com treinamentos continuados através de parceria com o SENAC (Serviço Nacional de Aprendizagem Comercial) de Natal.

\section{h) Preço:}

A estratégia de preço já consiste em uma ferramenta de atratividade do Corredor Cultural visto seu baixo custo para sua realização mesmo que alguns estabelecimentos modifiquem seu atual valor cobrado para a entrada de visitantes. Devendo ser concedidos descontos na entrada para estudantes em todos os estabelecimentos que cobram valor em separado do que é cobrado pelo trajeto feito com guiamento. De uma forma geral o preço deverá ser acessível a diferenciados públicos que desejam conhecer ou realizar o trajeto novamente.

No ano de 2012 o preço cobrado para adentrar alguns prédios históricos não estava valorado como deveria e com isso o custo de manutenção não foi repassado a estas instituições fazendo com que os atrativos deixem de ser revitalizados como deveria ocorrer. Além deste fator, identificou-se haver descaso do poder público e das Instituições responsáveis por tal serviço em elaborarem estratégias de mudanças para valorização do Corredor Cultural como alternativa de desenvolvimento dos bairros inseridos no trajeto, da cidade de Natal e circunvizinhas, e até mesmo de todo o estado do Rio Grande do Norte.

\section{CONCLUSÃO}

As análises apresentadas neste artigo propiciaram realizar um diagnóstico desse importante atrativo turístico para Natal, que é o seu Corredor Cultural. Tanto a análise feita utilizando-se da Matriz SWOT quanto à da Tabela de Avaliação e Hierarquização dos Atrativos mostraram-se adequadas. 
Considera-se que o artigo atingiu seu objetivo ao mostrar a relevância do Corredor Cultural como agregador de valor para o destino Natal. O diagnóstico realizado possibilita apontar um conjunto de prioridades para a melhor implantação e gestão do Corredor Cultural de Natal, as quais são apresentadas a seguir:

- A avaliação e o controle das ações planejadas para o Corredor Cultural devem ocorrer por meio de fiscalização continuada aos ambientes, prédios e praças que o constituem.

- Devem ser atribuições dos gerentes/administradores de cada lugar a ser visitado às de zelar, limpar, restaurar, manter e ampliar ações de acordo com as necessidades temporais de cada monumento, prédio, praça.

- Necessita-se da realização de reuniões sistemáticas com todos os representantes escolhidos a colaborarem na manutenção do Corredor Cultural, com pauta a ser debatida previamente entre os mesmos.

- Deverão ser instituídos controles de fluxo de pessoas que visitam cada local para que sejam viabilizadas estimativas de recebimento de pessoas, bem como sejam disponibilizadas estas informações pela Secretaria de Turismo do Município para facilitar o monitoramento de seus resultados, acompanhamento e especialmente a contabilização de pessoas que optam pelo Turismo Cultural na cidade de Natal.

- Algumas atividades deverão ser pensadas a estimular a participação da comunidade e dos turistas, com apresentações teatrais nos ambientes visitados, por exemplo, as quais auxiliarão aos guias de turismo a contar os detalhes históricos e mitos, estimulando, com isso, que o circuito possua valor agregado e possa atrair, cada vez mais, um número expressivo de pessoas, bem como fazer com que quem o visitou retorne e o faça com um "outro olhar" e outras expectativas e experiências.

Ao seguir os apontamentos feitos ao longo deste artigo, acredita-se que o destino Natal tem condições de atingir um melhor posicionamento no mercado, tornando-se mais competitivo. Porém, também se compreende que para isso acontecer, medidas devem ser tomadas por parte dos representantes do governo e empresários do setor turístico, concentrando-se nos gaps que faltam ser preenchidos, e que foram destacados nos resultados aqui apresentados.

Vale ressaltar que o artigo traz análises feitas basicamente sob o ponto de vista de seus autores, enquanto investigadores e analistas. Assim, entende-se que conhecer a 
percepção de terceiros (como turistas, residentes, gestores e empresários), é de grande importância para o complemento das informações expostas neste artigo, pois trará ainda mais reflexões e contribuições sobre o tema.

Os autores também entendem que com as constantes mudanças dos espaços urbanos, uma nova análise como esta deverá ser feita num prazo de dez anos. Principalmente, por que Natal será sede da Copa 2014 e até lá, terá recebido muitos investimentos injetados no setor de turismo, deixando-os como legado. Assim, será possível comparar o que foi alterado com o passar do tempo, se o destino melhorou ou não o seu posicionamento, e se o Corredor Cultural tornou-se um dos seus principais produtos turísticos ou se continuou em segundo plano.

\section{REFERÊNCIAS}

ARK, L. A. V. der; RICHARDS, G. Attractiveness of cultural activities in European cities: A latent class approach. Tourism Management, v. 27, p. 1408-1413, 2006.

BAHIA. Estado recebe mais estrangeiros que Ceará e Pernambuco juntos. Disponível em: <http://www.bahia.com.br/es/node/14644>. Acesso em: 03/04/2013.

BARRETTO, M. Turismo e legado cultural: As possibilidades do planejamento. Campinas, SP: Papirus, 2000. (Coleção Turismo).

BRASIL. Anuário Estatístico de Turismo - 2012. Disponível em: <http://goo.gl/I9A2f. 2012>. Acesso em: 15/04/2013.

Convênio $N^{\circ} 740418$ com a Secretaria de Estado do Turismo do RN para Elaboração de Estudos e Projetos com vistas a Reabilitação Urbana do Centro Histórico de Natal - RN. Diário Oficial da República Federativa do Brasil. Poder Executivo, Brasília, DF, 02 de jul. 2010. Seção 1. 2010a.

Estudo da Demanda Turística Internacional 2004 - 2008. Brasília: Ministério do Turismo, 2010b.

Ministério do Turismo. Turismo Cultural: orientações básicas. 3. ed. Brasília, 2010c.

Ministério do Turismo. Um tour pelos patrimônios brasileiros. Disponível em: <http://www.turismobrasil.gov.br/promocional/noticias/detalhe/noticia3.html>. 22 Out. 2010d. Acesso em: 03/04/2013. 
Ministério do Turismo. Programa de Regionalização do Turismo. Roteirização

Turística - Módulo Operacional 07. Brasília, 2005. 42 p.

Programa de Regionalização do Turismo - Roteiros do Brasil. Ministério do

Turismo: Produtos Turísticos. Brasília, 2004.

CHIAS, J. Turismo o Negócio da Felicidade. São Paulo: SENAC, 2007.

CHIOZZINI, D. Turismo cultural e educação patrimonial mais próximos. 2007. Disponível em: <http://www.labjor.unicamp.br/patrimonio/materia.php?id=147>. Acesso em: 23/11/2011.

COSMA, S.; NEGRUSA, A. The place of cultural tourism for Cluj-Napoca, Romania as a tourist destination. Wseas Transactions on Business and Economics, v. 7, n. 5, p. 403-13, 2008.

DIAS, R.; CASSAR, M. Fundamentos do Marketing Turístico. São Paulo: Pearson Prentice Hall, 2005.

FADE. Diagnóstico para o plano estratégico de Natal - uma metrópole em formação. Plano Estratégico de Desenvolvimento Sustentável para Região Metropolitana de Natal. Produto 2. Governo do Estado do Rio Grande do Norte - Natal Metrópole 2020. FADE- Fundação de Apoio ao Desenvolvimento da UFPE: Recife, novembro de 2006. Vol 1.

FERRAZ, V. S.; TRIGUEIRO, E. B. F.; TINOCO, M. B. de M. Turismo Cultural e Revitalização de Centro Antigo: reciclando arquitetura pré-moderna e moderna. Porto Alegre: 2007.

FUNARI, P. P.; PINSKY, J. Turismo e Patrimônio Cultural. São Paulo: Contexto, 2005.

GOMES, D. M. C. Turismo e museus: um potencial a explorar. In: FUNARI, P. P.; PINSKY, J. Turismo e patrimônio cultural. São Paulo: Contexto, 2005.

IEB. Corredor Cultural - Projeto de revitalização do centro histórico do Rio de Janeiro. Revista do Instituto de Estudos Brasileiros. v. 34, p. 63-69, 1992. Disponível em: <http://143.107.31.231/Acervo_Imagens/Revista/REV034/Media/REV34-09.pdf>. Acesso em: 10-04-2013.

KOTLER, P.; ARMSTRONG, G. Princípios de Marketing. Rio de Janeiro: LTC, 1999.

RIES, A.; TROUT, J. Posicionamento: a batalha por sua mente. São Paulo: MBooks, 2009. 
RODRIGUES, M. De quem é o patrimônio: Um olhar sobre a prática preservacionista em São Paulo. Revista do Patrimônio Histórico e Artístico Nacional, Brasília - DF, n.24, p. 195-203, 1996.

SETUR - SECRETARIA DE TURISMO DO ESTADO DO RIO GRANDE DO NORTE. Pesquisa Demanda Turística - Natal. 2002-2008. Natal, 2008.

SETUR - SECRETARIA DE TURISMO DO ESTADO DO RIO GRANDE DO NORTE. Termo de Referência para a elaboração de estudos e projetos com vistas à reabilitação urbana do centro histórico de Natal - RN. Natal, 2010.

SETURDE - SECRETARIA DE TURISMO E DESENVOLVIMENTO ECONÔMICO DE NATAL. Proposta preliminar de elaboração do Roteiro Pedestre - Cidade Alta/Ribeira. Natal, 2007.

SILVA, H. H.; TENCA, E. C.; SCHENINI, P. H.; FERNANDES, S. Planejamento Estratégico de Marketing. Rio de Janeiro: FGV, 2011.

SILVA, M. Cidades turísticas - Identidade e cenários de lazer. São Paulo: Editora Aleph, 2003.

SIMÃO, M. C. Preservação do Patrimônio Cultural em Cidades. Belo Horizonte: Autêntica, 2006.

WORLD ECONOMIC FORUM. The Travel \& Tourism Competitiveness Report. 2011.

Recebido em: 22-12-2012 (primeira versão)

Recebido em: 15-04-2013 (segunda versão)

Aceito para publicação em: 15-05-2013. 